Acta vet. scand. $1968,9,253-267$.

From the Department of Pathology, Royal Veterinary College, Stockholm, Sweden, and the Nutritional Pathology Division, Department of Pathology, New York State Veterinary College, Cornell University, Ithaca, USA.

\title{
ETIOLOGY AND PATHOGENESIS OF SO-CALLED MUCOID DEGENERATION OF THE NASAL CONCHAE IN THE HORSE
}

\author{
By \\ Sven Rubarth and Lennart Krook
}

In 1892 Sand described "Mucoid degeneration of the nasal conchae" in the horse. The disease has since received considerable attention in the literature; an exhaustive review was published by Espersen in 1962. Nonetheless, the morphologic nature of the disease is still not agreed upon. Espersen believed that the lesions resembled those of hyperparathyroidism. The same conclusion was reached by the present authors, and it is the object of this report to substantiate such a view.

The morphologic manifestation of hyperparathyroidism is generalized osteodystrophia fibrosa which, in turn is defined as an osteopenia due to excessive resorption of bone with fibrous tissue replacement. Two fundamentally different mechanisms are involved in resorption of bone, viz. osteoclasia and osteolysis. Whereas osteoclasia is a surface resorption brought about by the action of osteoclasts, osteolysis designates a deep-seated resorption in which mature osteocytes play the central role. Osteolysis has been the subject of several reviews (Bélanger et al. 1966; Brown et al. 1966; Henrikson 1968; Krook 1968). In very brief terms, osteolysis is characterized by enlargement of deep-seated osteocytes and their lacunae, sometimes to the point of confluence and, hence, formation of internal resorption cavities, simultaneous loss of matrix and minerals around such osteocytes, and metachromasia of the matrix involved. The latter criterion offers a simple and accurate method for the histologic demonstration of osteolysis. 


\section{MATERIAL AND METHODS}

Material from 10 cases of "mucoid degeneration of the nasal conchae" in the horse collected at the Department of Pathology, Royal Veterinary College, Stockholm, during the period 1929 through 1939 was studied. The age of the horses ranged from $1 / 2$ year to 2 years with an average of 10 months.

Tissues were re-embedded in paraffin, sectioned at 6 microns and stained with hematoxylin and eosin (H\&E), Prussian blue and with toluidine blue.

\section{RESULTS}

Excessive resorption of bone, fibrous tissue replacement and, to a lesser degree, osteoid apposition and, further, extravasation into loose connective tissue with eventual formation of cysts, constituted the morphologic changes common to all cases.

Resorption of bone was achieved mainly by accelerated osteolysis; osteoclasia occurred as a rare and rather insignificant event.

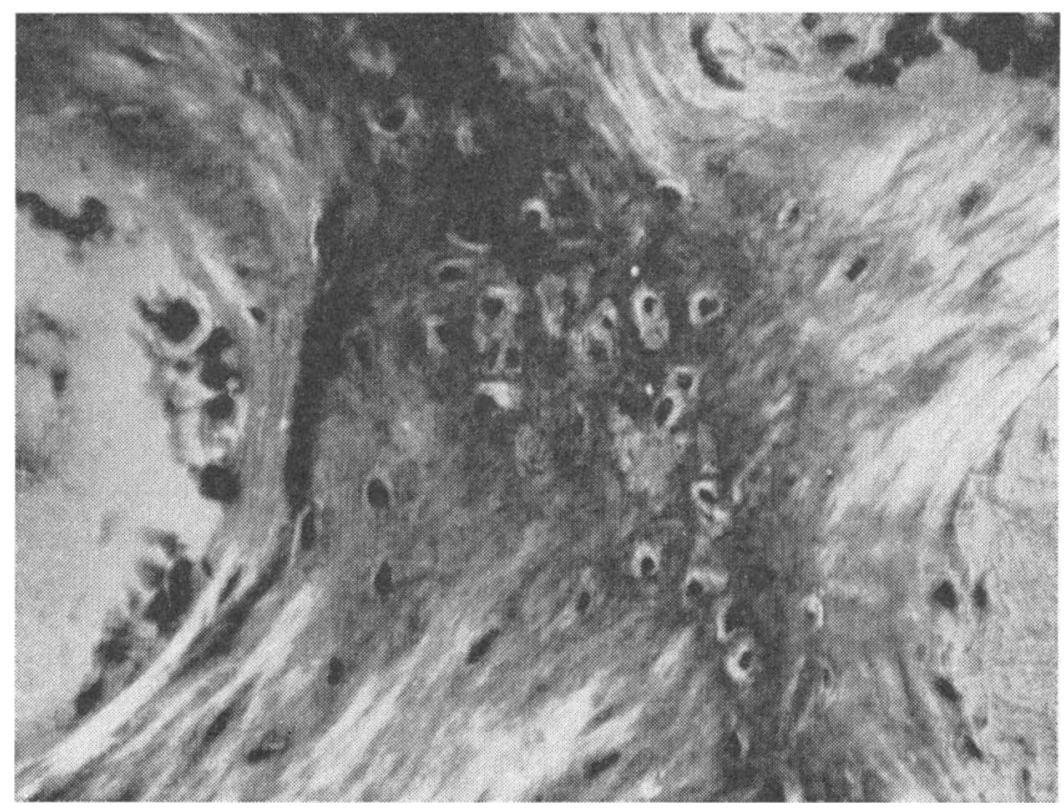

F i g u r e 1. (P. 1629/30). Maxilla, cancellous bone. Osteoblasts lining surface. Superficial osteocytes small. Size of osteocytes and intensity of metachromasia increasing toward center. Deep-seated lacunae void of cells and surrounding matrix no longer metachromatic. Note loss of birefringency toward center. Toluidine blue, polarized light, $\times 350$. 
Osteolysis concerned both cancellous and cortical bone. In cancellous bone the typical picture was that shown in Fig. 1, from a section of the maxilla. Young osteocytes just beneath the apposition surface were small and there was no metachromasia of surrounding matrix. Deeper in the bone tissue the osteocytes and, hence, their lacunae, gradually became larger. A diffuse metachromasia of the matrix increased in intensity toward the center. In the deepest part the enlarged lacunae contained no osteocytes or only remnants of pyknotic cells. With this cell death the adjacent matrix lost its metachromasia (Fig. 1)

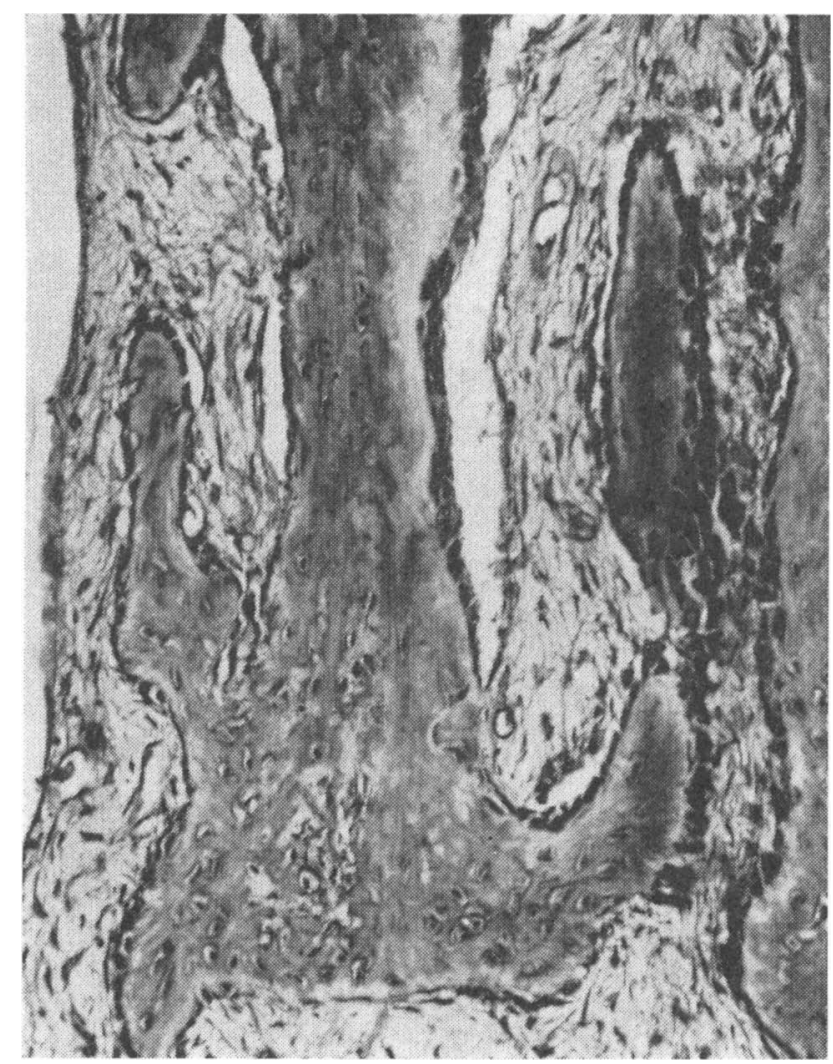

F i g u r e 2. (P. 701/29). Cancellous bone at first mandibular molar. Intense metachromasia in center of trabeculae. Thinning and disruption of trabeculae to the right. Internal resorption cavities by confluence of adjacent, enlarged osteocytic lacunae in lower part of figure. Fibrous tissue replacing disappearing bone. No osteoclasia. Toluidine blue, $\times 150$. 


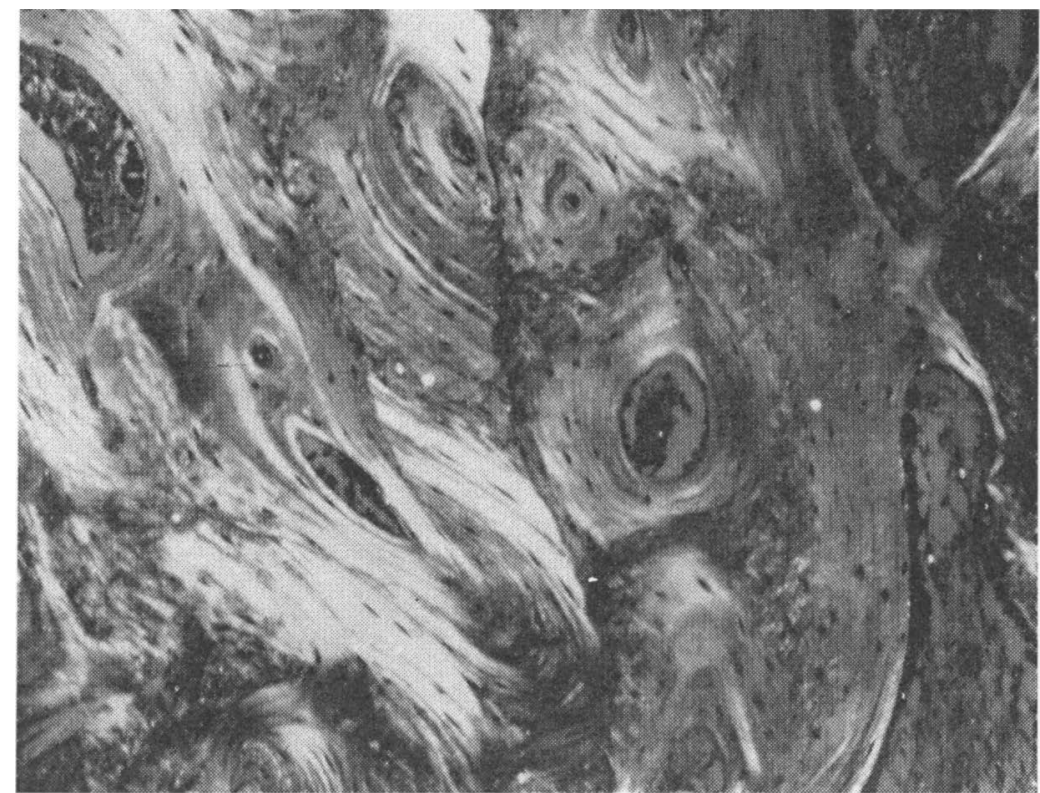

Fig u re 3. (P. 1629/30). Maxillary cortical bone at third premolar. Lytic resorption of interstitial lamellae and peripheral Haversian lamellae evidenced by metachromasia and loss of birefringency. Toluidine blue, partly polarized light, $\times 120$.

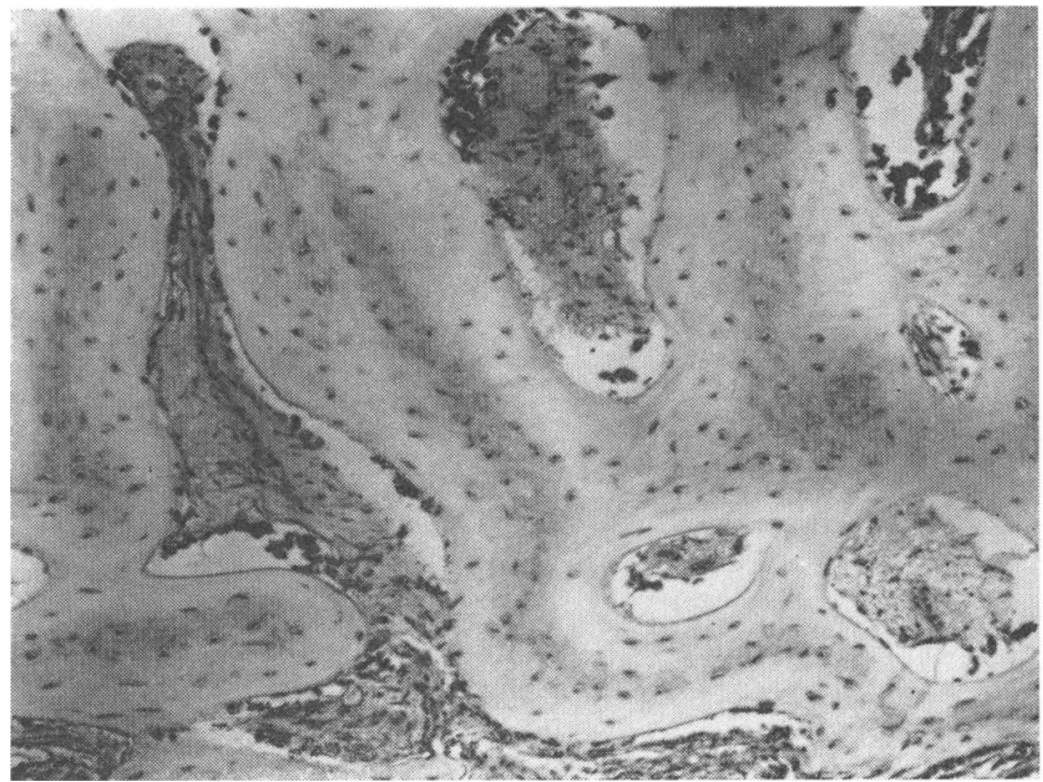

F i g u r e 4. Other area of section in Fig. 3. Widened Haversian and Volkmann's canals. Note metachromasia away from surfaces. Toluidine blue, $\times 120$. 
In the peripheral part of the trabeculae the collagen fibers exhibited intense birefringency but this was gradually lost as the lytic processes were intensified centrally (Fig. 1).

Apposition of osteoid was pronounced. Large osteoblasts covered the surface, sometimes in double layers (Figs. 1 and 2). However, osteolysis exceeded apposition and trabeculae therefore became thinner and, finally, disrupted (Fig. 2). The accelerated osteolysis sometimes resulted in internal resorption cavities by means of confluence of adjacent, enlarged osteocytic lacunae (Fig. 2).

Cortical bone covering the cancellous bone was likewise the site of osteolytic resorption. The interstitial lamellae and the peripheral Haversian lamellae of the osteon were sites of predilection (Fig. 3). Enlargement of lacunae, metachromasia and loss of birefringency were, again, observed as criteria of osteolysis. Internal resorption cavities and wide Haversian and Volkmann's canals were seen as intermediate stages (Fig. 4) toward the extreme shown in Fig. 5. Resorption was so advanced at that stage that only remnants of a few osteons were present.

Apposition was sometimes quite vivid along cortical bone undergoing lytic resorption. The osteoid was not mineralized as evidenced by the light pink ( $H \& E$ ) color of this osteoid seam (Fig. 6).

In a section of a maxillary molar root intense cementolysis was present (Fig. 7). The cementoid was refractive to toluidine blue and its cementocytes were relatively small. In the deeper parts facing the dentin, the cementocytes were considerably enlarged and the matrix intensely metachromatic. The alveolar bone support was completely lost with the periodontal space consisting of fibrous tissue only.

Osteoclasia was a quite rare finding. When it occurred (Fig. 8) it was confined to lamellated bone severely altered by osteolysis or to newly formed and poorly collagenized bundle bone.

The fibrous tissue that replaced the resorbed bone was usually quite immature. Some differentiation of the fibroblasts had occurred as visualized by moderate collagenization. Differentiation into osteoblasts was also apparent, and rather large islands of completely disorganized osteoid were occasionally present (Fig. 9).

Cyst formation was a prominent feature. The cysts were 


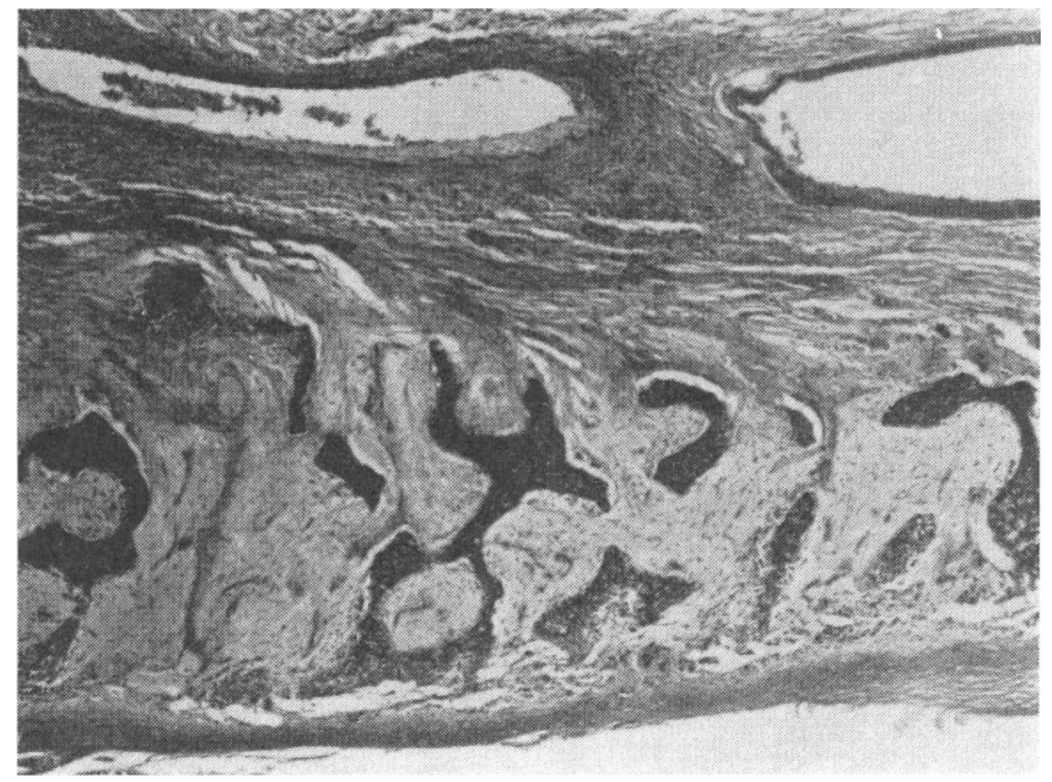

F i g u r e 5. Other area of section in Fig. 3. Advanced lytic resorption with only remnants of osteonic configurations. H\&E, $\times 45$.

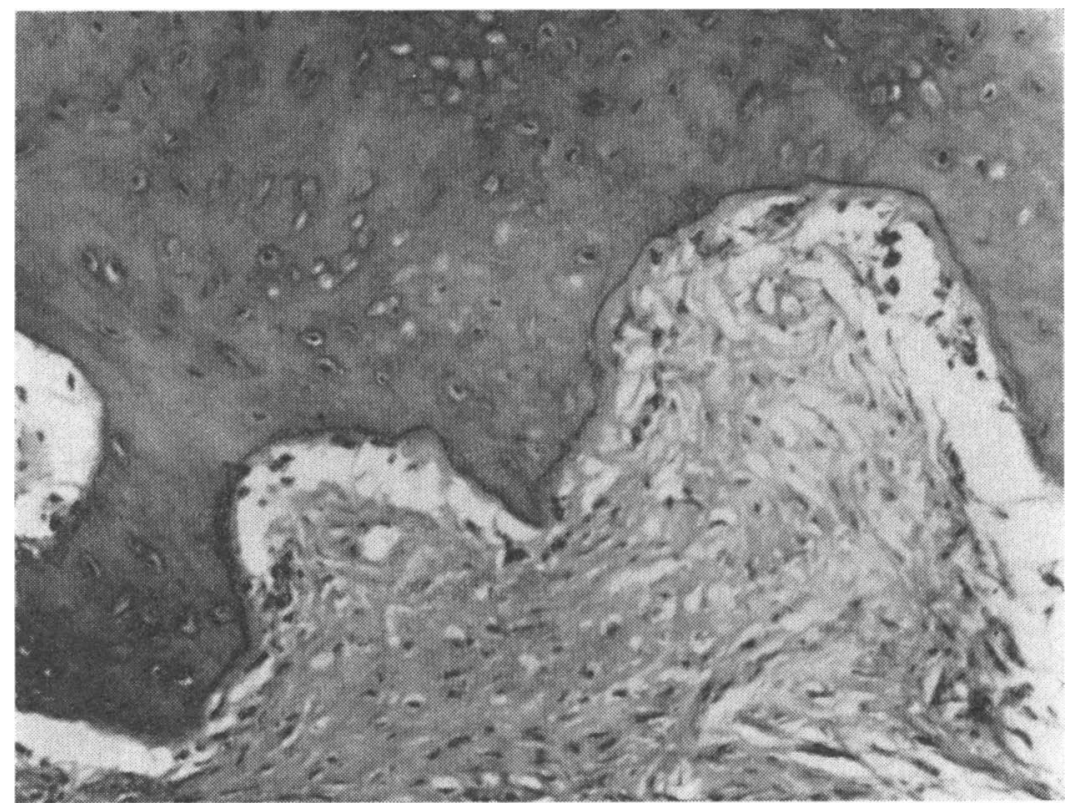

F i g u r e 6. (P. 1629/30). Maxilla, cortical bone. Intense deep-seated osteolysis evidenced by enlarged, sometimes acellular lacunae. Wide osteoid seam along apposition surfaces. Fibrous tissue replacement. No osteoclasia. H\&E, $\times 180$. 


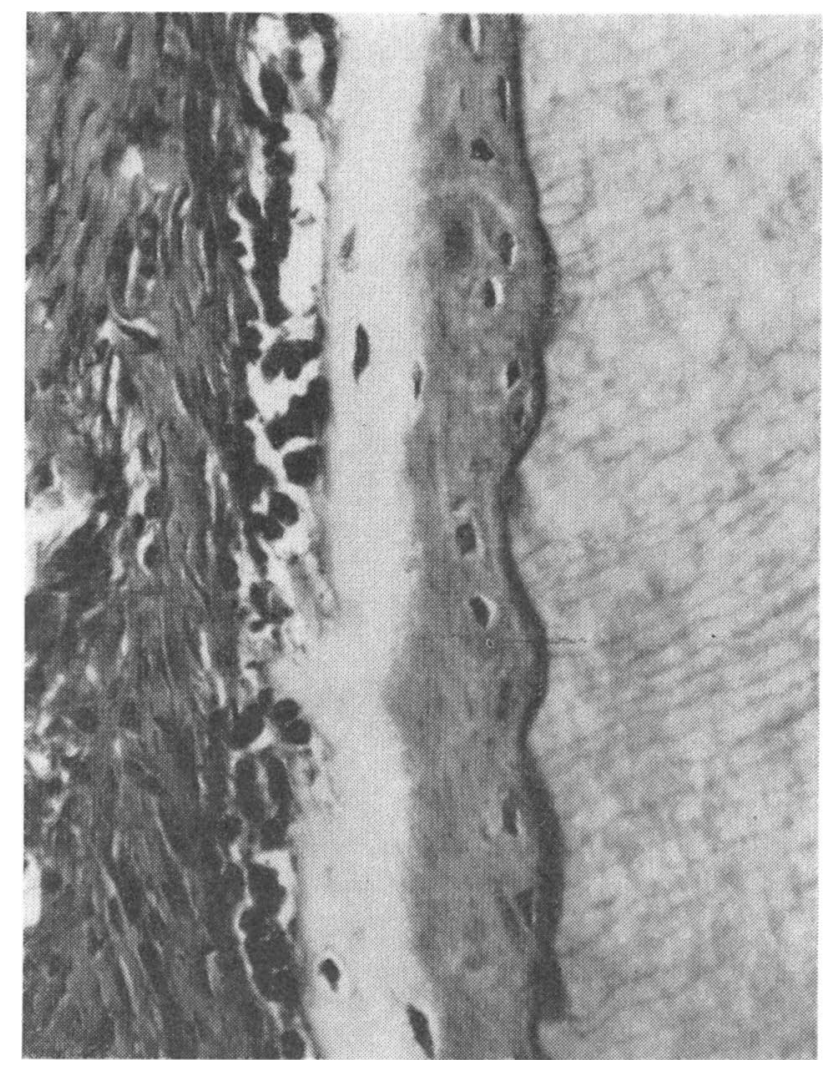

Fig u r e 7. (P. 701/29). Root of third maxillary premolar. From left to right: fibrous tissue of periodontal space, light layer of cementoid, deep layer of cementum with intensely metachromatic matrix. Dentin to the right. Toluidine blue, $\times 300$.

derived from hemorrhages. Diffuse extravasation from dilated vessels into the loose connective tissue was the initial stage (Fig. 10). Continued hemorrhages pushed the fibrous tissue peripherally and the wall of the expanding cyst cavity therefore consisted of compressed fibrous tissue. Hemolysis then resulted in formation of a structureless, slightly basophilic content of the cyst.

Due to hemorrhages, the connective tissue often contained a remarkable number of hemosiderin-laden macrophages (Fig. 11). As a rule rather than an exception, plasma cells were present, sometimes in great abundance in the connective tissue (Fig. 12). 


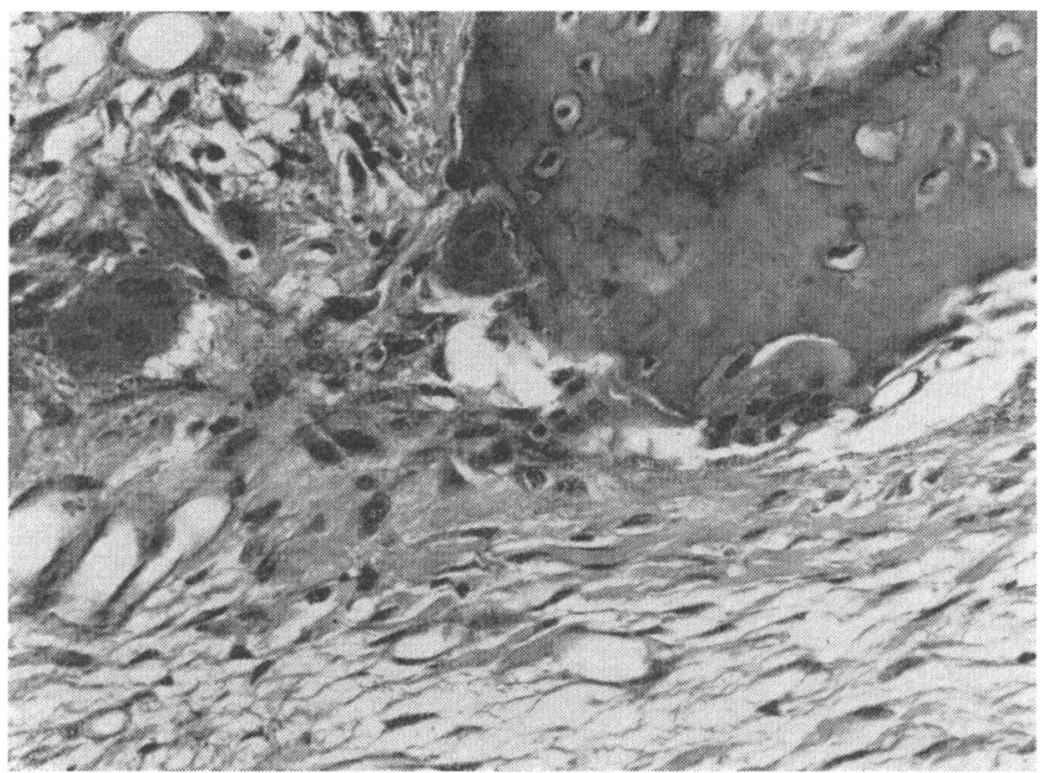

F i g u r e 8. (P. 29/31). Concha. Bone fragment with enlarged, sometimes acellular osteocytic lacunae. Two osteoclasts in Howship's lacunae, one trapped in replacing fibrous tissue. Note brush border of latter osteoclast. $\mathrm{H} \& \mathrm{E}, \times 375$.

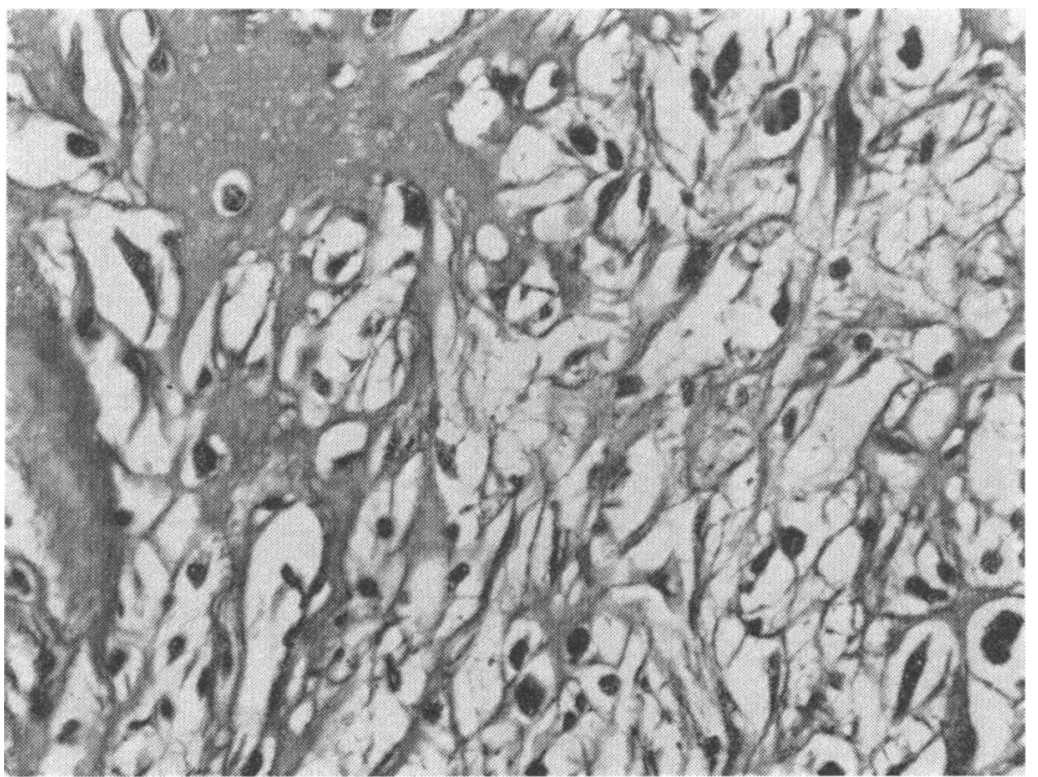

F i g u r e 9. (P. 682/31). Maxilla, lateral to root of second molar. Osteoid in upper left third of figure. Dark cells in loose connective tissue are plasma cells and hemosiderin-laden macrophages.

$\mathrm{H} \& \mathrm{E}, \times 400$. 
Minor hemorrhages would leak diffusely into the surrounding tissue without pushing it ahead. Once hemolyzed, it appeared as a greyish-blue structureless material between the connective tissue fibers (Fig. 13). This material never showed metachromasia with toluidine blue which also was the case with the contents of the cysts.

\section{DISCUSSION}

The morphologic diagnosis is unquestionably osteodystrophia fibrosa, and there is no need to discuss any differential diagnosis. Interpretation of the histologic picture prerequires appreciation of osteolysis. In agreement with previous studies on osteodystrophia fibrosa with special emphasis on the importance of osteoclasia versus osteolysis (Bélanger et al. 1966; Brown et al. 1966; Henrikson 1968), the present study showed that osteolysis is the major event in bone resorption. Fibrosis, hemorrhages and cyst formation are, naturally, consequences of excessive resorption.

The gradual thinning of trabeculae of cancellous bone toward the point of disruption is a most typical event in osteodystrophia fibrosa. Bélanger \& Migicovsky (1963) showed that tritiumlabelled thymidine injected into chickens could be detected autoradiographically after a few hours in young osteocytes of trabecular bone. After a few days the isotope occurred in more deeply located osteocytes and after still a few days - from 4 to 7 days after injection - radiothymidine could no longer be demonstrated. Bélanger (1965) interpreted this as evidence for "a constant replacement stream .. moving in from the border". With appreciation of Bélanger's concept of the turnover in trabecular bone, the disappearence of such bone in osteodystrophia fibrosa becomes the logical consequence of greater lysis than apposition. The potential space resulting from lysis is filled by the matrix formed at the surface and which starts to flow toward center with the "replacement stream". Therefore, when lysis exceeds apposition, bone volume is lost at the apposition surface, the trabeculae shrink and finally disrupt. These sequences of events, shown to be operative in the present material, are exactly the same by which the tubular cancellous bone of the turbinates are resorbed in atrophic rhinitis in swine (Brown et al.).

Prevalent concepts consider the cementum an inert tissue. Henrikson showed, however, with microradiography and histology that cementum, like other bone tissue, is metabolically 


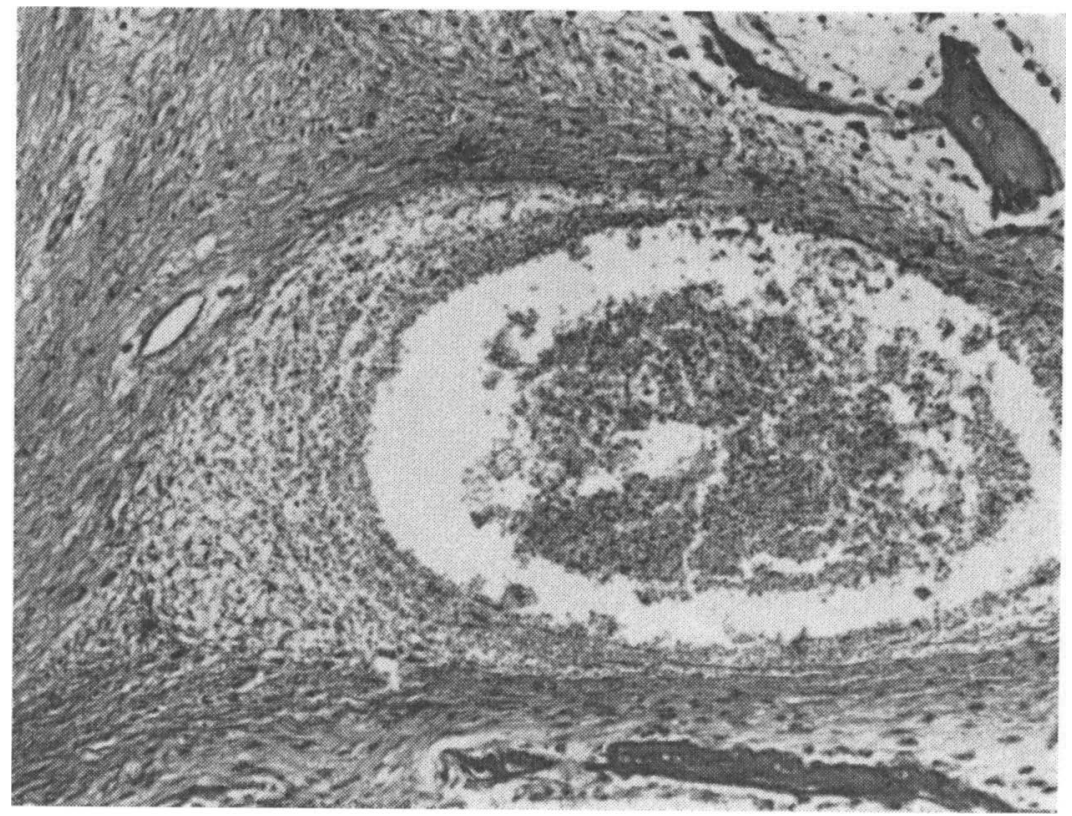

Figure 10 . (P. 555/31). Maxillary attachment of ventral concha. Dilated vessels with hemorrhage into surrounding connective tissue. $\mathrm{H} \& \mathrm{E}, \times 140$.

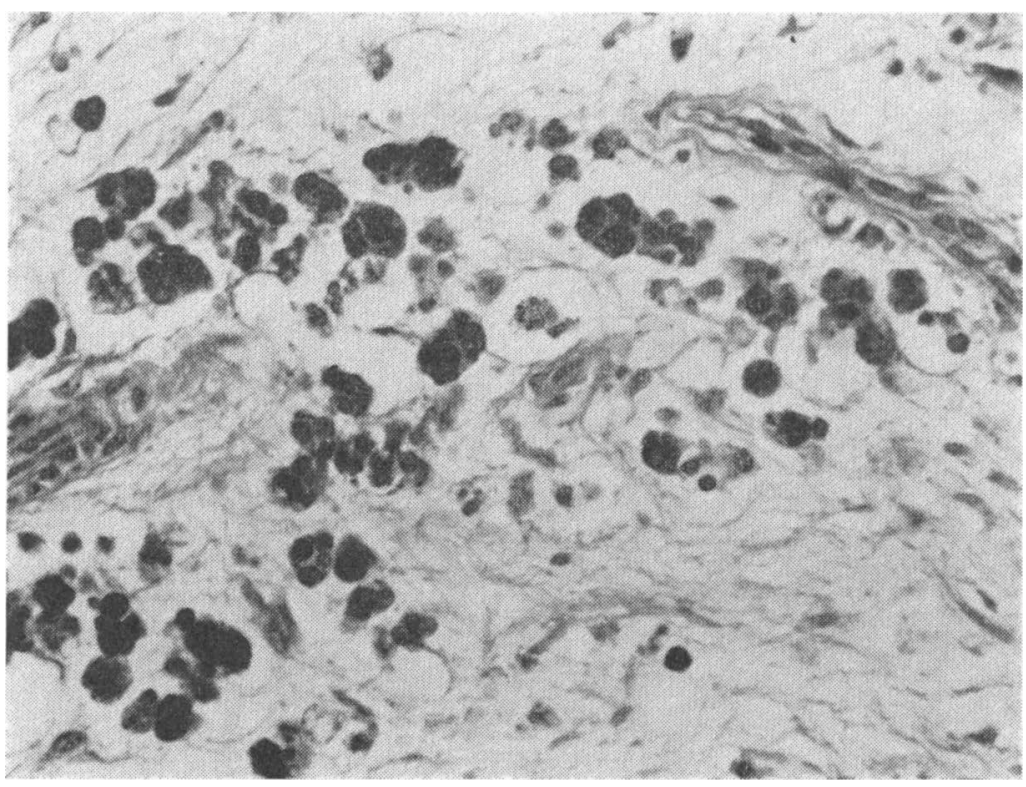

Figure 11. (P. 682/31). Same section as in Fig. 9. Hemosiderinladen macrophages in loose connective tissue. "Brown node". $\mathrm{H} \& \mathrm{E}, \times 450$. 
active. Bélanger (1968) demonstrated cementolysis by alpharadiography in rat molar roots and found it to be enhanced by parathormone injection. The present study is in agreement with the findings by Henrikson and by Bélanger.

Osteoid seams are diagnostic features or rickets and osteomalacia in which diseases the lack of mineralization of osteoid is ascribed to low serum ion product of calcium and phosphorus. The same explanation was applied for the osteoid seams in primary hyperparathyroidism by Boyce \& Jowsey (1966). On the other hand, osteoid seams are of consistent occurrence in nutritional secondary hyperparathyroidism induced by optimal calcium and excessive phosphorus feeding with markedly increased serum ion product (Krook \& Lowe 1964). It would therefore seem reasonable to interpret the osteoid seams in hyperparathyroidism as an expression of one mode of action by the parathormone, viz. prevention of mineralization of newly deposited osteoid. Such osteoid is manufactured in excess in late stages as an attempt to compensate for resorbed bone. If minerals were built in immediately into the osteoid, the calcium gained by accelerated resorption would be lost immediately. Such an event would therefore defeat the purpose of secondary hyperparathyroidism, i.e. to compensate for hypocalcemia.

Plasma cell infiltration of the replacing fibrous tissue was a prominent finding in the present material. The explanation remains theoretical. Plasma cell reaction would be expected as an immune response to a chronic infection. There were, however, no signs of chronic inflammation of the sinus or turbinate mucosa. A more attractive, but still theoretical explanation would be plasmocytosis as an expression of autoimmunity. During the excessive and prolonged resorption of bone, its organic matrix would hypothetically act as antigen against which plasma cell infiltration would appear as the source of antibody reaction.

Osteodystrophia fibrosa has been described only as a generalized disease in animals. Localized osteodystrophia fibrosa, such as it occurs in Paget's disease and in Albright's syndrome in man, is unknown in domestic animals. Although a large number of sections from the mandible, maxilla including the turbinates, and facial bones were examined in the present study, definite proofs of the generalized nature are lacking. There are, on the other hand, no reasons to believe, that the changes described would not be accentuations of a generalized osteopathy. 


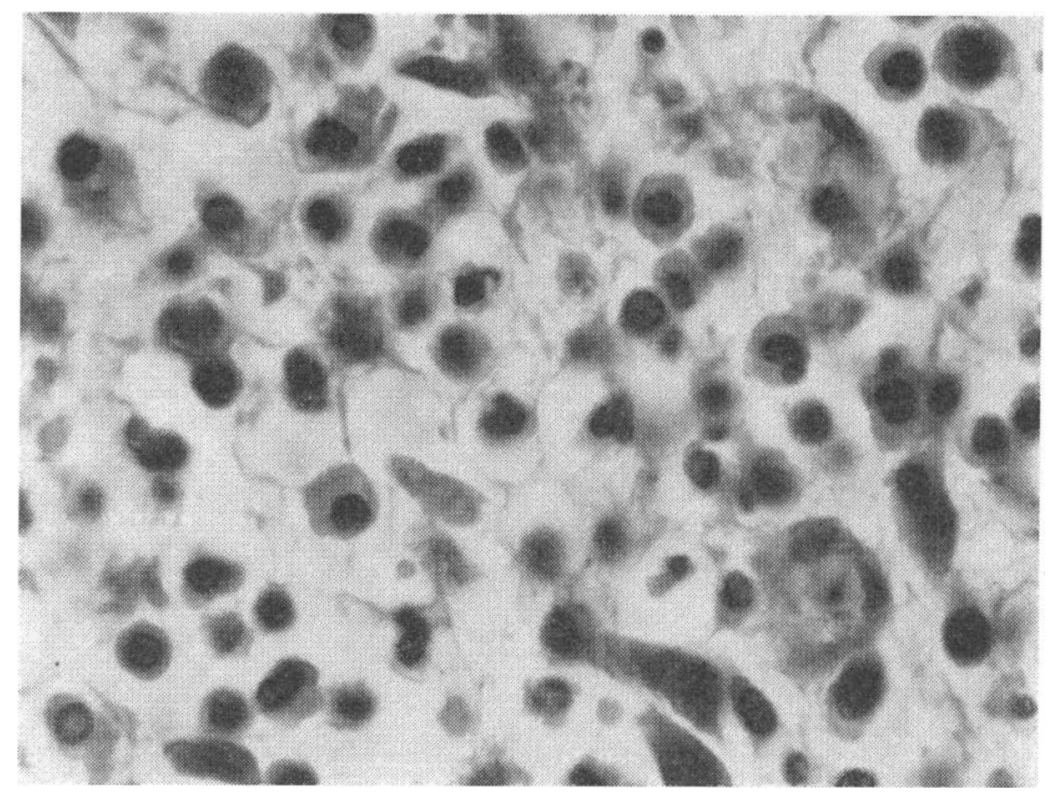

F i g u r e 12. (P. 682/31). Same section as in Fig. 9. Numerous plasma cells in loose connective tissue. H\&E, oil immersion, $\times 1180$.

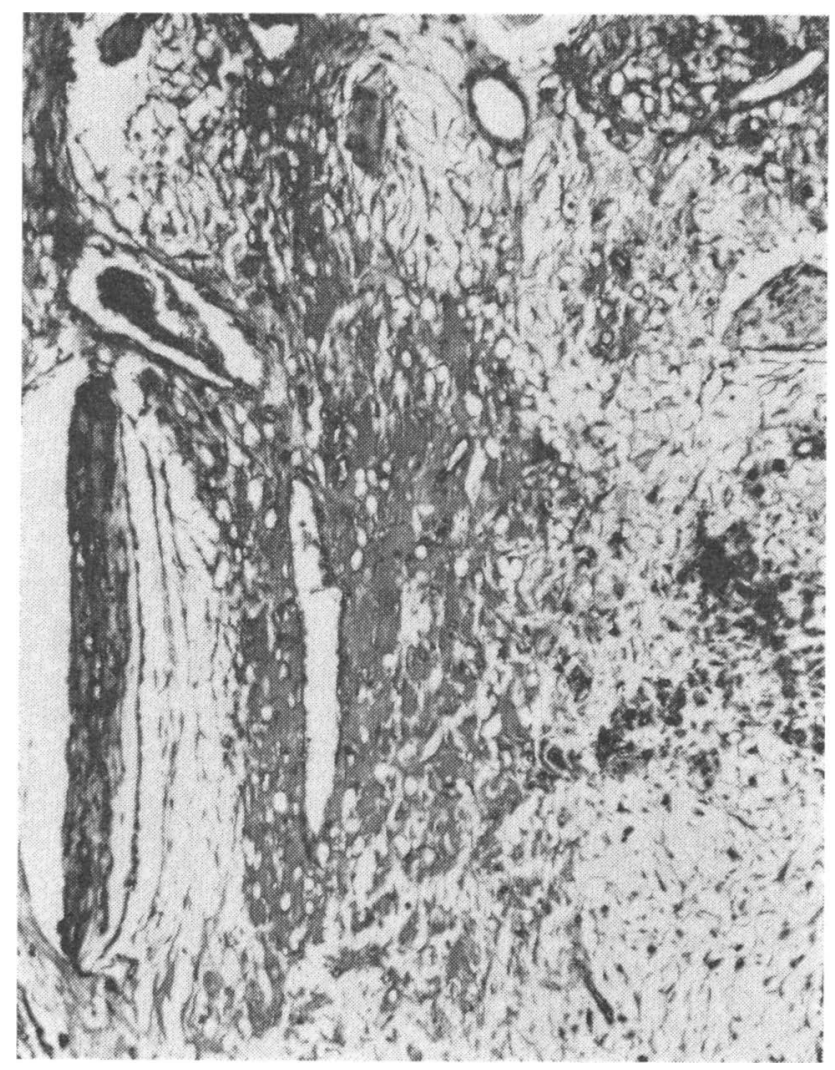

F i g u r e 13. (P. 701/29). Maxilla at third premolar. Hemolyzed blood around dilated vessels. No metachromasia. Toluidine blue, $\times 120$. 
Generalized osteodystrophia fibrosa equates hyperparathyroidism. The primary form can be discarded without much discussion. The probability that all these young horses would have a parathyroid neoplasia is nil. The renal secondary form is as unlikely; symptoms of renal insufficiency exceed those of osteopathy in this form. We are then left with nutritional secondary hyperparathyroidism. The histories of our cases include no information on the nutritional background of the mare or of the foals. It is known, however, that when horses still had a place in city life, excessive grain feeding (with low calcium and high phosphorus contents) at the expense of hay feeding (with balanced proportions of calcium and phosphorus) was prevalent. It is no coincidence that material of the disease in question has been collected from city areas.

The gnathic bones have repeatedly been shown to be sites of predilection in nutritional secondary hyperparathyroidism; Krook \& Barrett (1962) in the monkey; Krook et al. (1963) in the cat; Krook \& Lowe in the horse; Brown et al. in swine; Henrikson in the dog; review by Krook (1968). It has been shown in mice that the normal turnover rate in alveolar bone is twice as high as in frontal bone (Baunhammers et al. 1965). When excessive resorption is induced, it is then natural that the most severe lesions should appear in the jaws.

The osseous lesions in the disease under consideration certainly are more fulminant than in the typical form (if there is such a one) of nutritional secondary hyperparathyroidism. It should be emphasized that the present material is from young horses, who have normally a high metabolic rate in the skeleton.

No histochemical evidence for mucoid degeneration was found in the present study. The original term applied to the disease is therefore inappropriate. The term multiple jaw cysts is only a symptomatic one. The disease should, in our opinion, be classified as nutritional secondary hyperparathyroidism of severe degree.

\section{REFERENCES}

Baumhammers, A., R. E. Stallard \& H. S. Zander: Remodelling of alveolar bone. J. Periodont. 1965, 36, 439-442.

Bélanger, L. F.: Osteolysis: An outlook on its mechanism and etiology. In Parathyroid Hormone, Ultrastructure Secretions and Function. Ed. P. G. Gaillard, R. V. Talmage \& A. Budy., University of Chicago Press, Chicago 1965, 137-143. 
Bélanger, L. F.: Resorption of cementum by cementocyte activity ("Cementolysis"). Presented at Amer. Ass. Anat., New Orleans 1968.

Bélanger, L. F. \& B. B. Migicovsky: Bone cell formation and survival under various conditions. Anat. Rec. 1963, 145, 385-390.

Bélanger, L. F., T. Semba, S. Tolnai, D. H. Copp, L. Krook \& C. Gries: The two faces of resorption. Proc. 3rd Europ. Symp. Calcif. Tissues. Ed. H. Fleisch, H. J. J. Blackwood \& M. Owen. Springer, Berlin - Heidelberg - New York 1966, 1-10.

Boyce, D. \& J. Jowsey: Measurements of osteoid tissue in primary hyperparathyroidism. Mayo Clin. Proc. 1966, 41, 836-838.

Brown, W. R., L. Krook \& W. G. Pond: Atrophic rhinitis in swine; etiology, pathogenesis and prophylaxis. Cornell Vet. 1966, 56, Suppl. 1, 1-128.

Espersen, G.: Multiple kæbecyster hos hesten. C. Fr. Mortensen, Copenhagen 1962, 1-111.

Henrikson, P.-A.: Periodontal disease and calcium deficiency; An experimental study in the dog. Acta odont. scand. 1968, 26, suppl. 50, 1-132.

Krook, L.: Metabolic bone diseases of endocrine origin. In Joest, E.: Handbuch der speziellen pathologischen Anatomie der Haustiere. Ed. J. Dobberstein, G. Pallaske \& H. Stünzi. Parey, Hamburg and Berlin 1968, Vol. I.

Krook, L. \& R. B. Barrett: Simian bone disease - a secondary hyperparathyroidism. Cornell Vet. 1962, 52, 459-492.

Krook, L. \& J. E. Lowe: Nutritional secondary hyperparathyroidism in the horse. Path. Vet. 1964, 1, suppl. 1, 1-98.

Krook, L., R. B. Barrett, K. Usui \& R. E. Wolke: Nutritional secondary hyperparathyroidism in the cat. Cornell Vet. 1963, 53, 224-240.

Sand, G.: Slimdegeneration af Muslingbenene hos Hesten. Månedsskr. Dyrlæg. 1892, 4, 297-310.

\section{SUMMARY}

Following a description of the histopathology of so-called mucoid degeneration of the nasal conchae in the horse, the authors conclude that the morphologic nature of the disease is osteodystrophia fibrosa. The lesions are believed to be expressions of nutritional secondary hyperparathyroidism.

\section{ZUSAMMENFASSUNG}

Ätiologie und Pathogenese der so-genannten Schleimdegeneration der Nasenmuscheln des Pferdes.

Nach einer Beschreibung der Histopathologie der so-genannten Schleimdegeneration der Nasenmuscheln des Pferdes, schliessen die Verfasser, dass das morphologische Bild der Krankheit der Osteodystrophia fibrosa entspricht. Es wird angenommen, dass die Veränderungen der Ausdruck ernährungsbedingtem sekundärem Hyperparathyreoidismus ist. 


\section{SAMMANFATTNING}

Etiologi och patogenes vid s. $k$. slemdegeneration $i$ näsmusslorna hos häst.

Efter histopatologisk undersökning av s. k. slemdegeneration i näsmusslorna hos häst drar författarna slutsatsen, att sjukdomens morfologiska natur är osteodystrophia fibrosa. Förändringarna är sannolikt uttryck för nutritionell sekundär hyperparathyreoidism.

(Received April 18, 1968). 